\title{
An assessment of water footprint for irrigated rice in Punjab
}

\author{
B.S. SIDHU ${ }^{1 *}$, RAKESH SHARDA ${ }^{2}$ and SANDEEP SINGH ${ }^{1}$ \\ ${ }^{1}$ Deptt. of Civil Engineering, Chandigarh University, Gharaun, SAS Nagar, Punjab; \\ ${ }^{2}$ Deptt. of Soil \&Water Engineering, PAU, Ludhiana-141004, Punjab, India. \\ *Corresponding author: sidhubs1969@gmail.com
}

\begin{abstract}
Water scarcity has become one of the highest risks for environmental and economic security worldwide. The water footprint for rice production, i.e., the total volume of freshwater consumed to produce a unit quantity rice has been estimated for three different agroclimatic zones of Punjab for the years 2000 to 2017. The results revealed that effective rainfall $\left(P_{\text {eff }}\right)$ improved in later years due to a change in crop calendar,legally enforced by an Act prohibiting the transplanting of paddy before a specified date. During the period of study, minimum crop evapotranspiration $\left(\mathrm{ET}_{\mathrm{c}}\right.$ ) was 4645 and maximum was $\mathrm{ET}_{\mathrm{c}}$ of 9511 $\mathrm{m}^{3} \mathrm{ha}^{-1}$ during 2014 and 2011, respectively. The green water footprint $\left(\mathrm{WF}_{\text {green }}\right)$ for rice varied from 646 litreskg-1 of rice during low rainfall years (2012) to 1149 litre $\mathrm{kg}^{-1}$ of rice during heavy rainfall (1192 $\mathrm{mm}$ ) during 2011.Out of a total water footprint $\left(\mathrm{WF}_{\text {total }}\right)$ of 2650 litre $\mathrm{kg}^{-1}$, the share of blue water footprint $\left(\mathrm{WF}_{\text {blue }}\right)$ was higher 1804 litre $\mathrm{kg}^{-1}(68 \%)$, indicating a need to improve on-farm irrigation management to conserve water resources.
\end{abstract}

Keywords: Weather parameters, evapotranspiration, water footprint, crop calendar

The water footprint of a product is the total volume of freshwater that is used or polluted during the production of the product (Hoekstra et al., 2009). The total water footprint $\left(\mathrm{WF}_{\text {total }}\right)$ of the growing crops is the sum of the green, blue, and grey components of its production process. Green water footprint $\left(\mathrm{WF}_{\text {green }}\right)$ describes the amount of water used from precipitation (green water resources), and blue water footprint $\left(\mathrm{WF}_{\text {blue }}\right)$ stands for the surface and groundwater used for irrigation (blue water resources). The grey water footprint $\left(\mathrm{WF}_{\text {grav }}\right)$ is the share of freshwater resources needed to assimilate aload of pollutants to the environment with regards to the existing ambient water quality standards (Hoekstra et al. 2011). The consumptive water footprint of the production of rice indicates the consumption of freshwater resources in different practices carried out during the entire cultivation process. Mekonnen and Hoekstra (2010) reported that between 1996 and 2005, the global water footprint for crop production was 7404 billion cubic meters per year ( $78 \%$ green, $12 \%$ blue, $10 \%$ grey). Total water footprint was very high for wheat (1087 billion cubic meters, $\mathrm{Gm}^{3}$ year $\left.{ }^{-1}\right)$, rice $\left(992 \mathrm{Gm}^{3}\right.$ year $\left.{ }^{-1}\right)$, and maize (770 $\mathrm{Gm}^{3}$ year $\left.^{-1}\right)$ (Mekonnen and Hoekstra (2011).

In India, rice is anessential food crop as it feeds more than $60 \%$ of its population. The area under rice has increased $143 \%$, i.e., from 30.8 million hectares in $1950-51$ to 43.8 million hectares during 2017-18, and its production has increased from 20.6 million tonnes in 1950-51 to 112.8 million tonnes during 2017-18, an increase of about 5.5 times (http://drdpat.bih.nic.in/). Similarly, area under rice in Punjab has increased tremendously from 390 thousand hectares in 1970-71 to 3065 thousand hectares in 2017-18, andproductivity in Punjab increased from 2,774 $\mathrm{kgha}^{-1}$ in 1970-71 to $4344 \mathrm{kgha}^{-1}$ in 2017-18. Thus, there is positive growth in the area, productivity, and production of rice in the state over the years. The Punjab state, having only $1.5 \%$ of the total geographical area of the country, contributes more than one-fourth of rice to the central pool for the last four decades.

Rice, a water-guzzling crop, occupies about threefourth of the cultivated area in Punjab during the summer season. The water requirement of rice is about 120 to $150 \mathrm{~cm}$ (Brar et al., 2015). More than $71 \%$ of its irrigation water requirement is met through groundwater, resulting in a declining underground water table at an alarming rate. Consequently, the Central Ground Water Board (CGWB)has estimated that the overall stage of groundwater development of the state is $165 \%$, and $79 \%$ area is over-exploited. The CGWBhas warned that "if the exploitation of state underground water resources continues at the current rate, renders Punjab into a desert within 25 years" (CGWB, 2018).

During April-June in Punjab, there is high atmospheric 
demand for water as the weather is hot and dry, relative humidity is low, wind speed is high, and the temperature is also high. There is hardly any rainfall during May-June, except for some pre-monsoon showers in some years. Thus, crops grown in this period have very high evapotranspiration (ET) and irrigation needs. The present study is an attempt to quantify the total water footprint of transplanted rice, considering a large amount of surface and groundwater use in rice production. This assessment may, in turn, guide the policymakers and other stakeholders to plan the optimal use of available freshwater in the production of rice and thereby control the declining water table and conserve the already limited natural resources in the state.

\section{METHOD AND MATERIALS}

\section{The study area}

Punjab is located in northern India between $29^{\circ} 30^{\prime}$ $\mathrm{N}$ to $32^{\circ} 32^{\prime} \mathrm{N}$ latitude and $73^{\circ} 55^{\prime} \mathrm{E}$ to $76^{\circ} 50^{\prime} \mathrm{E}$ longitude, at an altitude ranging from $230 \mathrm{~m}$ to $700 \mathrm{~m}$ above mean sea level. It has a geographical area of $50362 \mathrm{~km}^{2}$ of which about $41250 \mathrm{~km}^{2}$ is under the plough, and the rice-wheat cropping system occupies more than $80 \%$ of this area. Climatically, it has three major seasons - summer season from April to June, rainy season from July to September, and winter season from December to February. The average temperature varies from $34^{\circ} \mathrm{C}$ in June to $13^{\circ} \mathrm{C}$ in January but the highest being as high as $48^{\circ} \mathrm{C}$ in summer and lowest near to freezing point in winter. The average annual rainfall varies from $1250 \mathrm{~mm}$ in the north to $350 \mathrm{~mm}$ in the southwest, and more than 70 percent of it occurs from July to September, i.e., during the monsoon season. The climatic variations have resulted in a variety of soils in Punjab -the north-western part mainly dominated by calcareous soil, the eastern part by loamy to clayey soil, and central part by sandy loam to clayey soils, with the $\mathrm{pH}$ ranging from 7.8 to 8.5 . Nowonder, due to the massive production of food grains (31.67 million tonnes in 2017-18), Punjab has been rightly named as the breadbasket of India, but the prevailing soil and climate conditions in the state culminate into a wide range of crops and vegetation.

For this study, daily meteorological parameters of representing stations of each zone (Table 1) have been used for the study period (2000-2017) to work out the water footprint of irrigated rice for Punjab. The weather parameters used for the study have been sourced from Punjab Agricultural University, Ludhiana. The soil type has been taken as clay loam for the sub-mountainous zone (SMZ), loamy sand for south-western zone (SWZ), and sandy loam for the central plain zone (CPZ), for as these classes dominate the main rice-growing area in these zones of the state. The data regarding the area of rice transplanted on different dates in different zones and different years has been collected from the Department of Agriculture and Farmers Welfare, Punjab.

\section{Methodology}

The methodology for 'water footprint assessment' explained in 'the water footprint assessment manual' (Hoekstra, 2011) followed to work out the water footprint of the production of rice in Punjab. The FAO-56-PM model (Allen et al., 1998) used to estimate the reference evapotranspiration (ET $)$ using CROPWAT 8.0 software. For working out the crop evapotranspiration $\left(\mathrm{ET}_{\mathrm{c}}\right.$ ), the following equation was employed

$$
\mathrm{ET}_{\mathrm{c}}=\mathrm{K}_{\mathrm{c}} \times \mathrm{ET}_{\mathrm{o}}
$$

The $\mathrm{K}_{\mathrm{c}}$ value represents crop-specific water use and required for accurate estimation of the irrigation requirement of the crop. For the present study, adopted the $\mathrm{K}_{\mathrm{c}}$ values for initial, mid, and end phases (1.15, 1.36 and 0.86 , respectively) from Kaur et al. (2017) who have estimated the $\mathrm{K}_{\mathrm{c}}$ values for different stages of rice crop grown under different transplanting dates for Ludhiana. ET expresses the evaporating power of the weather at a given location and a specific time of the year and does not reflect the soil and crop characteristics.

Effective precipitation $\left(P_{e f f}\right)$ is that part of the total rainfall which is retained by the soil and is potentially available for meeting the crop water requirement. Generally, it is less than the total amount of rainfall as, in reality, the crop cannot appropriately use the whole of the rain owing to the surface run-off or deep percolation losses (Dastane, 1978). The $P_{\text {eff }}$ for rice crop was also computed by CROPWAT 8.0. $\mathrm{ET}_{\mathrm{o}}$ was determined using weather parameters for the year 2000 to 2017 for different zones (Table 1). The average surface runoff factor for Punjab is $13 \%$ through rainfall in Kharif, and deep percolation losses from rice fields are about $60 \%$ (Prihar et al., 1993).

To calculate the irrigation requirement $(I R)$ took the difference between crop water requirement (CWR) and $\mathrm{P}_{\text {eff }}$ The irrigation requirement is zero if $\mathrm{P}_{\text {eff }}$ is larger than the CWR. Therefore,

$$
I R=\max \left(0, C W R-P_{e f f}\right)
$$

Green water evapotranspiration $\left(E T_{\text {green }}\right)$ is the ET of 
Table 1:Geographical coordinates of selected agroclimatic zones of Punjab

\begin{tabular}{llllll}
\hline Sl.no. & Agroclimatic zone & Representing station & Latitude & Longitude & Altitude \\
\hline 1. & South-western zone (SWZ) & Bathinda & $30^{\circ} 17^{\prime} \mathrm{N}$ & $74^{\circ} 58^{\prime} \mathrm{E}$ & $211 \mathrm{~m}$ amsl \\
2. & Central plain zone (CPZ) & Ludhiana & $30^{\circ} 55^{\prime} \mathrm{N}$ & $75^{\circ} 54^{\prime} \mathrm{E}$ & $247 \mathrm{~m}$ amsl \\
3. & Sub-mountainous zone (SMZ) & BallowalSaunkhari & $31^{\circ} 65^{\prime} \mathrm{N}$ & $76^{\circ} 23^{\prime} \mathrm{E}$ & $357 \mathrm{~m}$ amsl \\
\hline
\end{tabular}

the rainfall. It is the minimum of total $\mathrm{ET}_{\mathrm{c}}$ and $\mathrm{P}_{\text {eff }}$ Blue water evapotranspiration $\left(E T_{\text {blue }}\right)$, in other words, field ET of irrigation water, is equal to the total $\mathrm{ET}_{\mathrm{c}}$ minus $\mathrm{P}_{\text {eff }}$, but zero when $\mathrm{P}_{\text {eff }}$ exceeds $\mathrm{ET}_{\mathrm{c}}$ :

$$
\begin{aligned}
& E T_{\text {green }}=\min \left(E T_{c}, P_{\text {eff }}\right) \\
& E T_{\text {blue }}=\max \left(0, E T_{c}-P_{\text {eff }}\right)
\end{aligned}
$$

Both the $\mathrm{WF}_{\text {blue }}$ and $\mathrm{WF}_{\text {green }}$ are indicators of the consumptive amount of water by the rice crop. In contrast, the $\mathrm{WF}_{\text {grey }}$ indicates water quality.

The $\mathrm{WF}_{\text {grey }}$ accounts fora load of pollutants added during the crop season to the freshwater resources. This pollution happens due to the application of the chemical fertilizers and plant protection chemicals in the field. There is no consideration of $\mathrm{WF}_{\text {grey }}$ in the present investigation following Zhuo et al. (2016); Bosire et al. (2017) and Civit et al. (2018), and the calculated $\mathrm{WF}_{\text {total }}$ of the rice cultivation as the sum of the green and blue components.

The accumulation of daily $E T\left(\mathrm{~mm} \mathrm{day}^{-1}\right)$ over the entire growing period was used to calculate the green and blue components in crop water use $\left(C W U, \mathrm{~m}^{3} \mathrm{ha}^{-1}\right)$.

$$
\begin{aligned}
& \text { CWU green }=10 \times \sum_{d=1}^{\text {lgp }} \text { ET green } \\
& \text { CWUblue }=10 \times \sum_{d=1}^{\text {lgp ETblue }}
\end{aligned}
$$

Where $E T_{\text {green }}$ and $E T_{\text {blue }}$ represent green water evapotranspiration, and the blue water evapotranspiration respectively. Factor 10 is for the conversion of water depths in millimetres into water volumes per land surface in $\mathrm{m}^{3} \mathrm{ha}^{-1}$, $\lg p$ stands for the length of the growing period in days. The summation is done over the entire growing period,i.e., from the day of planting (day 1 ) to the day of harvest.

\section{RESULTS AND DISCUSSION}

\section{Variation in the weather conditions}

In Punjab, the average minimum and maximum temperature during the rice crop season (May-October) ranged between $23.2-24.5^{\circ} \mathrm{C}$ and $34.3-36.1{ }^{\circ} \mathrm{C}$. The southwestern zone (SWZ) is relatively warmer than the central plain zone (CPZ) conversely, the sub-mountainous zone (SMZ) in the northern region of the state was coolest among the selected locations

The lowest mean temperature recorded at Ballowal Saunkhari(SMZ) was $28.6^{\circ} \mathrm{C}$, followed by $29.6^{\circ} \mathrm{C}$ at CPZ and $30.2^{\circ} \mathrm{C}$ at Bathinda (SWZ) (Fig. 1). The maximum and minimum temperatures at different zones of Punjab increased linearly with the varying rate at different locations, except for the maximum temperature, which showed a slightly decreasing trend at SWZ (@ - $\left.-0.014{ }^{\circ} \mathrm{Cyear}^{-1}\right)$. Observed a high variation in the rainfall during cropping season at different locations. The mean (2000-2017) rainfall was 369.9 $\mathrm{mm}$ at SWZ, $781.8 \mathrm{~mm}$ at SMZ and $610.4 \mathrm{~mm}$ at CPZ. The lowest rainfall only $162.6 \mathrm{~mm}$ was recorded during the year 2000 in SWZ that was $355.4 \mathrm{~mm}$ during 2002 at CPZ and $500.0 \mathrm{~mm}$ during 2012 at SMZ. The entire Punjab state received, the least crop season rainfall amount of 367.4 and $432.8 \mathrm{~mm}$ during 2012 and 2002, respectively. Contrarily, the highest rainfall of $558.4 \mathrm{~mm}$ (during 2016), $1133.5 \mathrm{~mm}$ (during 2008) and $1192.0 \mathrm{~mm}$ (during 2011), in respective zones.

\section{Reference evapotranspiration (ET)}

The rate of ET ${ }_{0}$ was too high during the May-June due to higher environmental temperatures and almost dry weather conditions. The month of May and June recorded a maximum rate of ET followed by July and August, and subsequently, it declined during September, October, and November. The gradual decrease in the mean ETo has been recorded from crop initiation (May) until its maturation phase (October) at different regions owing to the temperature and rainfall variations. In different years the range of the ETo was 4004 to $1954 \mathrm{~mm}$ at SWZ, 3824 to $1822 \mathrm{~mm}$ at SMZ and 3634 to $1673 \mathrm{~mm}$ at CPZ. Higher environmental temperatures accelerated the seasonal ET rainfall played the inhibitory role in this acceleration. Therefore, the heavy rainfall periods experienced lower ET than low rainfall years and vice-versa.In different years, with $1003.1 \mathrm{~mm}$ mean EToSWZ experienced the highest rate of ET followed by 

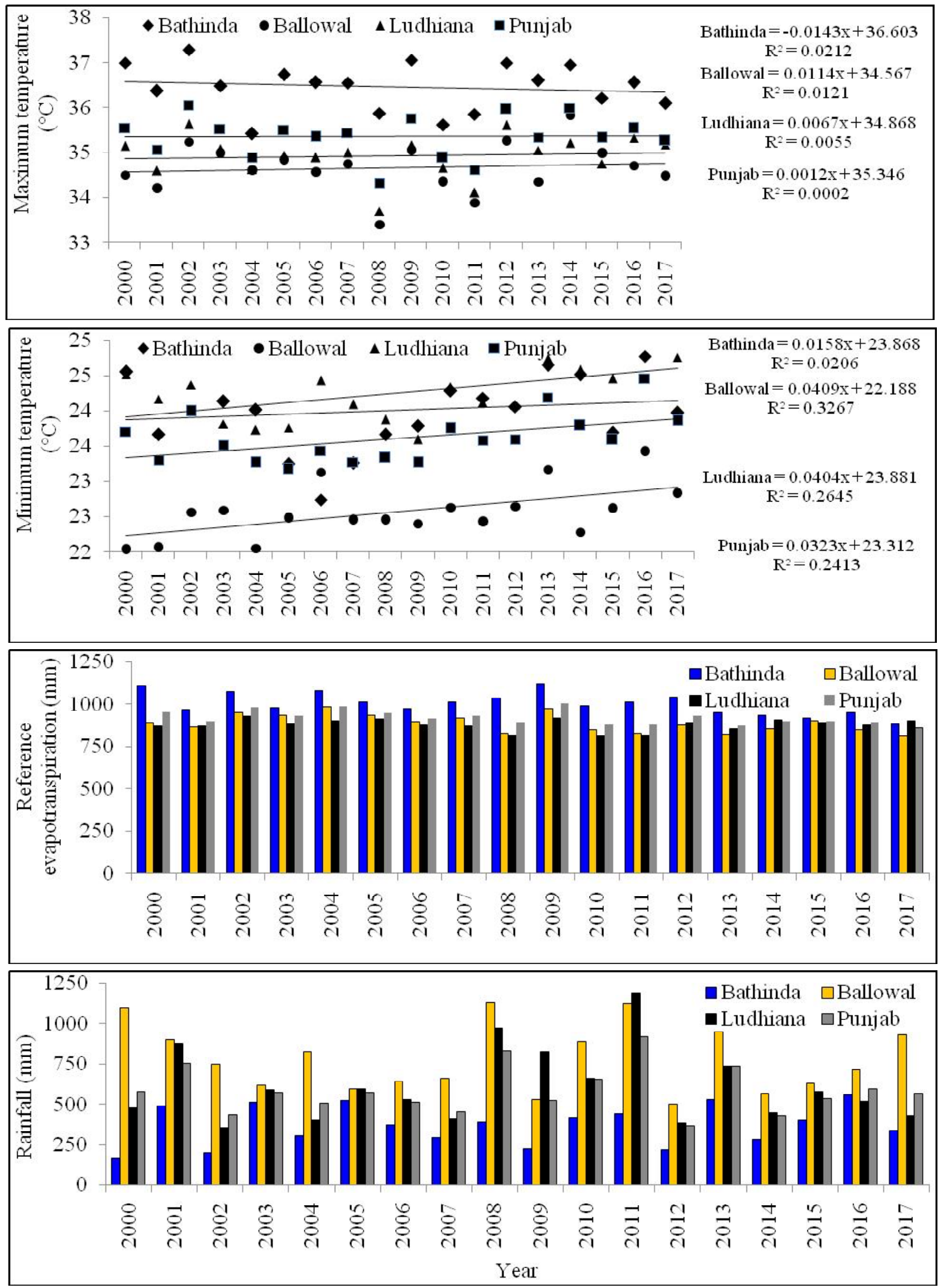

Fig. 1: Variation in weather conditions in different zones 


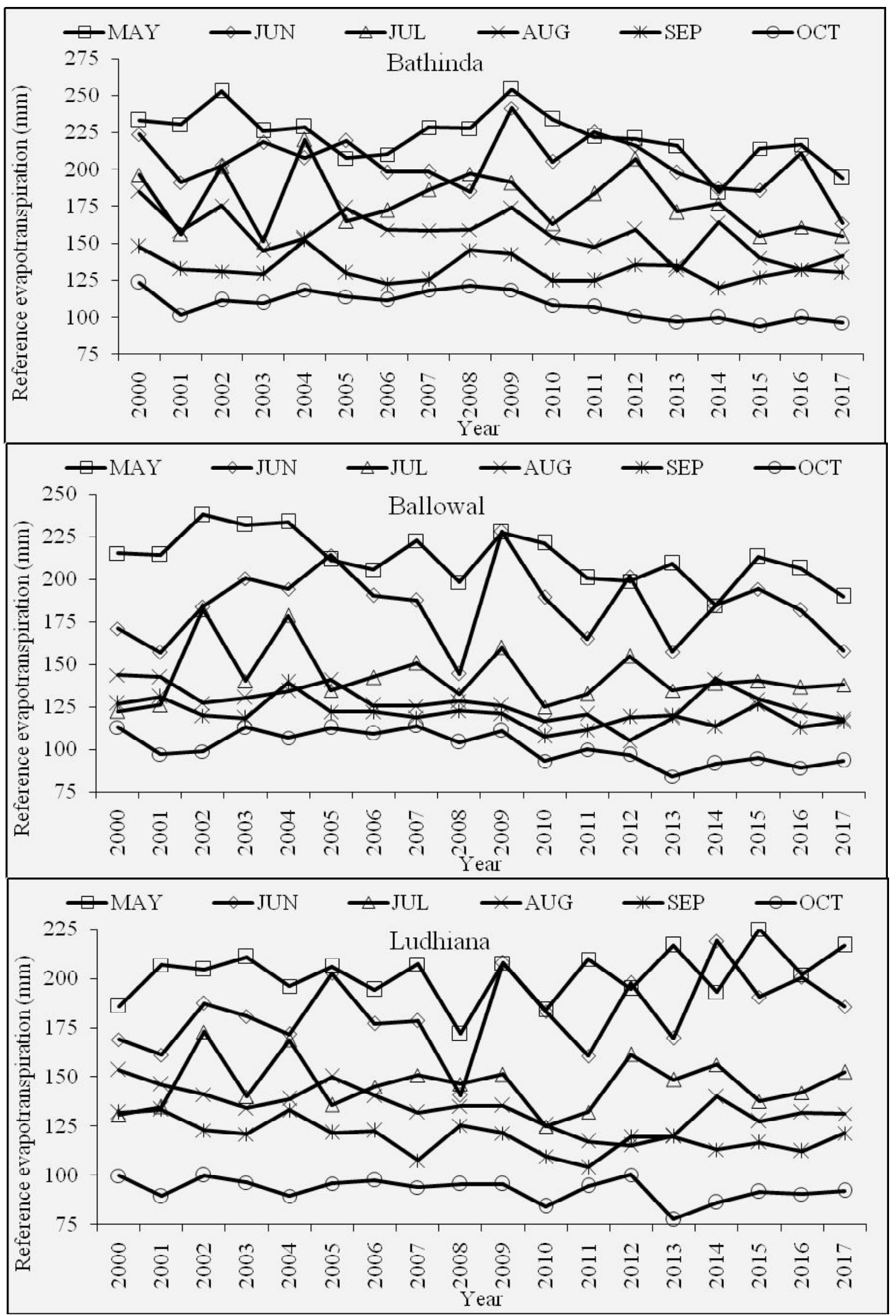

Fig.2:Reference evapotranspiration (ETo) in different zones of Punjab 


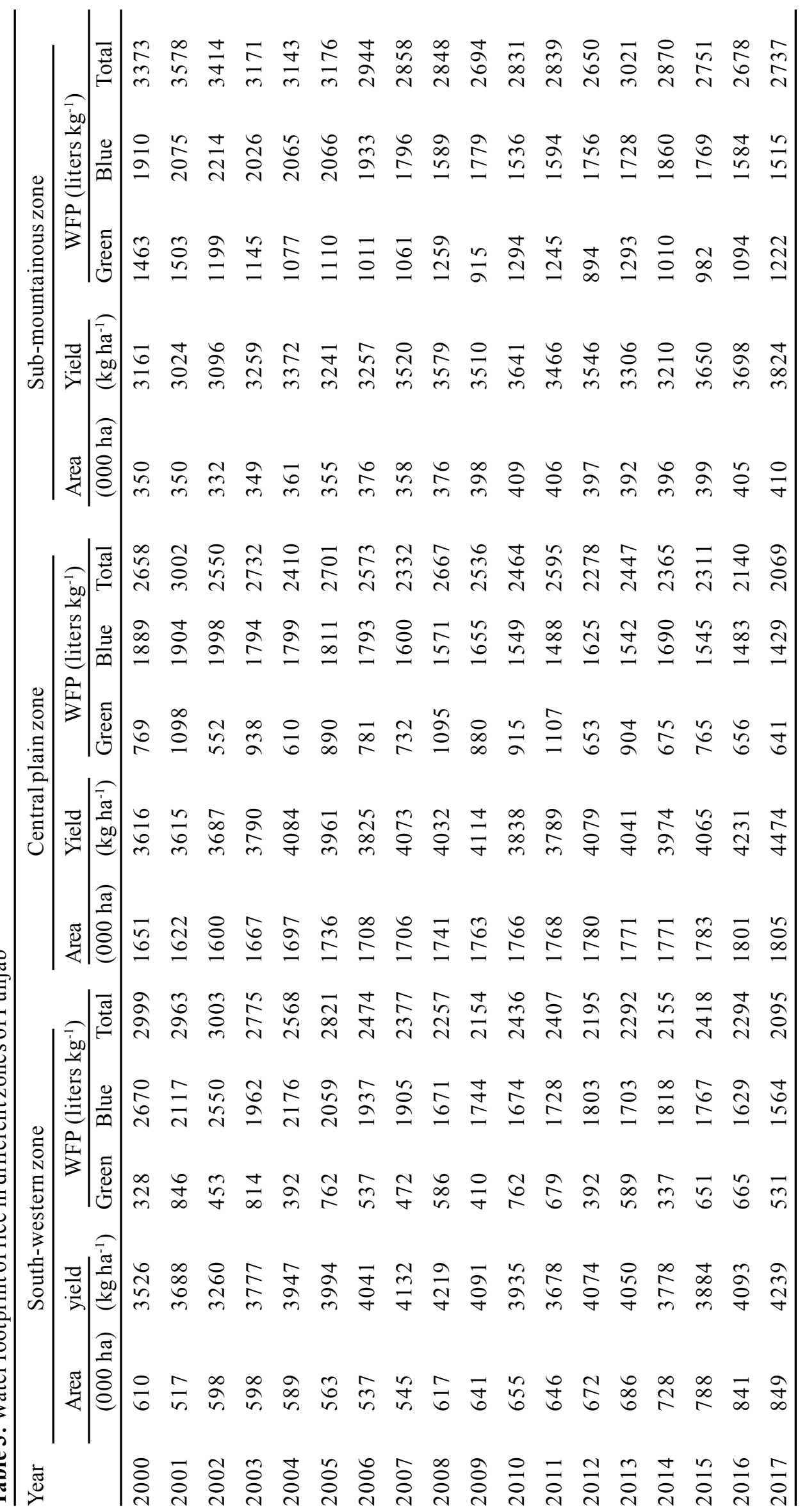


Table 2: Effective precipitation, crop evapotranspiration and precipitation deficit in rice season in Punjab

\begin{tabular}{|c|c|c|c|c|c|c|c|c|c|c|c|c|}
\hline \multirow[t]{2}{*}{ Year } & \multicolumn{3}{|c|}{ SWZ } & \multicolumn{3}{|c|}{$\mathrm{CPZ}$} & \multicolumn{3}{|c|}{ SMZ } & \multicolumn{3}{|c|}{ Punjab } \\
\hline & $\mathrm{P}_{\text {eff }}$ & ETc & $\begin{array}{l}\text { Deficit } \\
\text { rain (\%) }\end{array}$ & $P_{\text {eff }}$ & ETc & $\begin{array}{l}\text { Deficit } \\
\text { rain (\%) }\end{array}$ & $\mathrm{P}_{\text {eff }}$ & ETc & $\begin{array}{l}\text { Deficit } \\
\text { rain }(\%)\end{array}$ & $\mathrm{P}_{\text {eff }}$ & ETc & $\begin{array}{l}\text { Deficit } \\
\text { rain (\%) }\end{array}$ \\
\hline 2000 & 1530 & 2060 & -34.6 & 4409 & 5770 & -30.9 & 8681 & 11504 & -32.5 & 4873 & 6445 & -32.2 \\
\hline 2001 & 4379 & 5712 & -30.5 & 6882 & 9058 & -31.6 & 8414 & 11093 & -31.8 & 6558 & 8621 & -31.5 \\
\hline 2002 & 1212 & 1515 & -25.0 & 3199 & 4151 & -29.8 & 6950 & 9020 & -29.8 & 3787 & 4895 & -29.3 \\
\hline 2003 & 4318 & 5868 & -35.9 & 5455 & 7290 & -33.6 & 5491 & 7246 & -31.9 & 5088 & 6801 & -33.7 \\
\hline 2004 & 2492 & 3026 & -21.4 & 3810 & 4804 & -26.1 & 6675 & 8058 & -20.7 & 4325 & 5296 & -22.4 \\
\hline 2005 & 4787 & 6286 & -31.3 & 5148 & 6903 & -34.1 & 5591 & 7464 & -33.5 & 5175 & 6884 & -33.0 \\
\hline 2006 & 3360 & 4188 & -24.6 & 4189 & 5545 & -32.4 & 5381 & 7146 & -32.8 & 4310 & 5626 & -30.5 \\
\hline 2007 & 2615 & 3331 & -27.4 & 3781 & 4950 & -30.9 & 5788 & 7586 & -31.1 & 4062 & 5289 & -30.2 \\
\hline 2008 & 3023 & 3798 & -25.6 & 8477 & 10681 & -26.0 & 9855 & 12410 & -25.9 & 7119 & 8963 & -25.9 \\
\hline 2009 & 1859 & 2479 & -33.3 & 6422 & 8521 & -32.7 & 4667 & 6231 & -33.5 & 4316 & 5744 & -33.1 \\
\hline 2010 & 3897 & 5183 & -33.0 & 6154 & 8251 & -34.1 & 8157 & 10663 & -30.7 & 6070 & 8032 & -32.3 \\
\hline 2011 & 3968 & 5367 & -35.3 & 8434 & 10810 & -28.2 & 9522 & 12356 & -29.8 & 7308 & 9511 & -30.1 \\
\hline 2012 & 2020 & 2694 & -33.4 & 3509 & 4757 & -35.6 & 4794 & 6486 & -35.3 & 3441 & 4646 & -35.0 \\
\hline 2013 & 4750 & 6072 & -27.8 & 6399 & 7977 & -24.7 & 8674 & 11071 & -27.6 & 6607 & 8374 & -26.7 \\
\hline 2014 & 2665 & 3481 & -30.6 & 3799 & 4986 & -31.2 & 4084 & 5470 & -33.9 & 3516 & 4645 & -32.1 \\
\hline 2015 & 3721 & 4912 & -32.0 & 5181 & 6892 & -33.0 & 5811 & 7730 & -33.0 & 4904 & 6511 & -32.8 \\
\hline 2016 & 5062 & 6749 & -33.3 & 4075 & 5324 & -30.7 & 6091 & 7961 & -30.7 & 5076 & 6678 & -31.6 \\
\hline 2017 & 2984 & 3731 & -25.0 & 3135 & 3951 & -26.0 & 7937 & 10424 & -31.3 & 4686 & 6035 & -28.8 \\
\hline Mean & 3258 & 4247 & -30.4 & 5137 & 6701 & -30.5 & 6809 & 8884 & -30.5 & 5068 & 6611 & -30.4 \\
\hline
\end{tabular}

SMZ (888.0 $\mathrm{mm})$ and CPZ (329 $\mathrm{mm})$. The mean ETo for the rice crop period for whole Punjab state was $923.0 \mathrm{~mm}$ (Fig. 2).

\section{Effective rainfall $\left(P_{\text {eff }}\right)$ and crop evapotranspiration $\left(E T_{e}\right)$}

$\mathrm{P}_{\text {eff }}$ in Punjab state ranged from 3411 to $7308 \mathrm{~m}^{3} \mathrm{ha}^{-1}$ for ETc range of $4645-9511 \mathrm{~m}^{3} \mathrm{ha}^{-1}$. There was $\mathrm{g}$ deficit rainfall from $74.1 \%$ (2004) - 76.8\% (2012) in rice crop. The high $\mathrm{P}_{\text {eff }}$ was able to meet the high ETc demand at various temporal and spatial environments (Table 2). The maximum $\mathrm{P}_{\text {eff }}$ was 5062, 9855 and $8477 \mathrm{~m}^{3} \mathrm{ha}^{-1}$ while, the highest ETc of rice was 6749, 12410 and $10810 \mathrm{~m}^{3} \mathrm{ha}^{-1}$, at SWZ, SMZ and $\mathrm{CPZ}$, respectively. The ETc simultaneously increased with $\mathrm{P}_{\text {eff }}$ and vice-versa. Hence for low rainfall years, a large part of the ETcrequirement was met by applying irrigation from surface and groundwater. Therefore, under low rainfall (arid/semi-arid) zones, a higher portion of the precipitation may be converted as the $\mathrm{P}_{\text {eff }}$ by reducing the surface run-off and deep percolation losses through improved crop management practices. The results (Table 2 ) revealed that during the early years, the $\mathrm{P}_{\text {eff }}$ was lower $\left(4873 \mathrm{~m}^{3} \mathrm{ha}^{-1}\right.$ during 2000 and $3747 \mathrm{~m}^{3} \mathrm{ha}^{-1}$ during 2002) that was insufficient to fulfil the crop water requirement. The consequent notification of "The Punjab Preservation of Subsoil Water Act" (referred as Act-2009) made it mandatory for all farmers "not to sow paddy nursery before $10^{\text {th }}$ day of May" and not to go for transplanting "before such date, as may be notified in this regard by the State Government" (Sharma et al., 2010). The adoption of improved water management practices, particularly the change in crop calendar enforced through notification of Act-2009, has considerably improved $\mathrm{P}_{\text {eff }}$ in later years $\left(7119 \mathrm{~m}^{3} \mathrm{ha}^{-1}\right.$ during 2008 and $7308 \mathrm{~m}^{3} \mathrm{ha}^{-1}$ during 2011). The date of transplanting was notified as $10^{\text {th }}$ June in 2009 and shifted to June $15^{\text {th }}$ by notification in 2014. This change of the date of transplanting has shifted the crop growing season to a period of low ET and to coincide it better with the onset of monsoon. Further, the evaporation losses are more than the transpiration losses during the early phases of crop growth because of the exposure of the large land surface to the sunlight. As the crop grows, the 


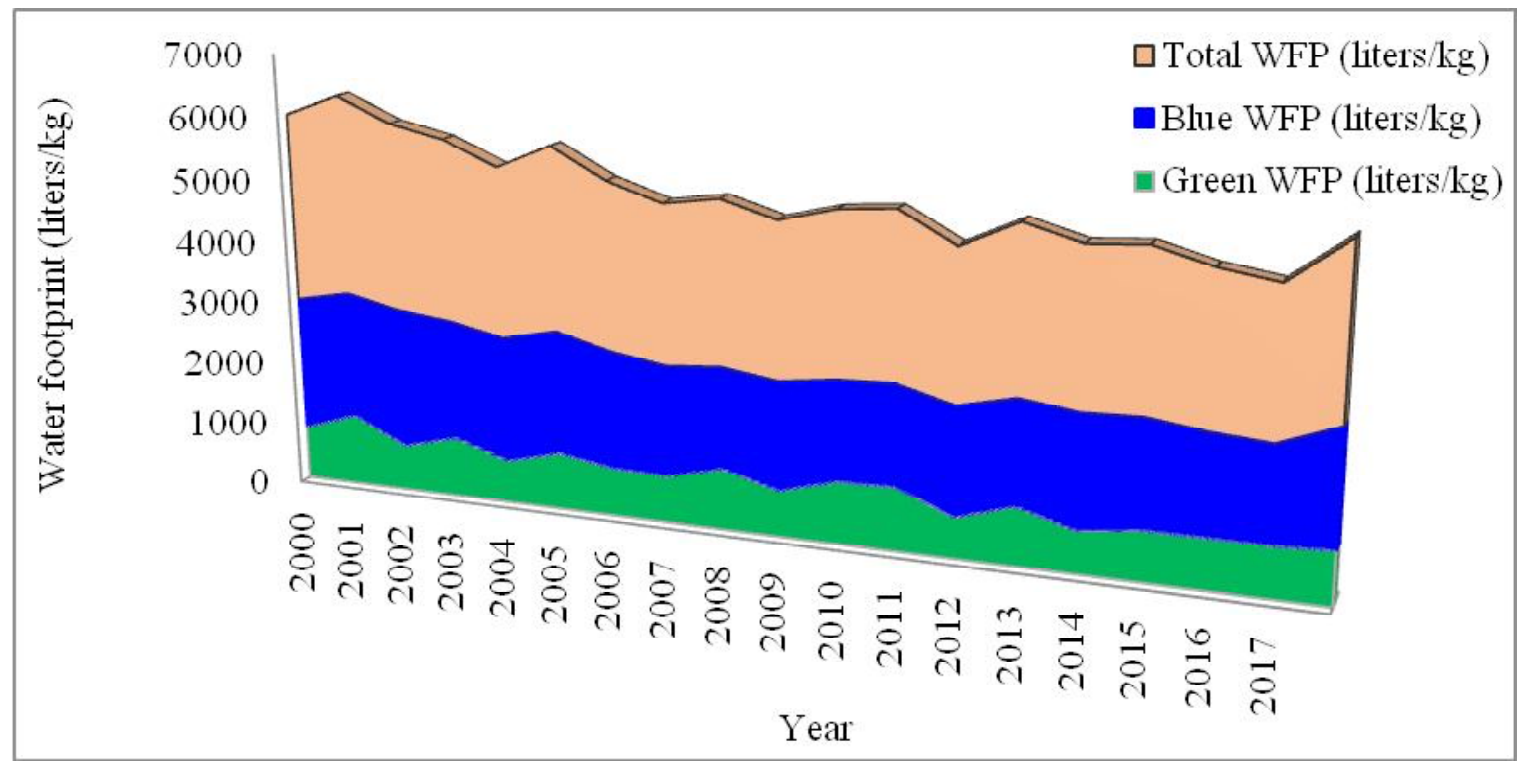

Fig. 3: Green, blue and total water footprints of rice in Punjab

transpiration exceeds the evaporation due to a fully developed crop canopy.

\section{Area and productivity of rice}

Both area and productivity of rice have considerably increased in Punjab. During 2000, the total area under rice cultivation was 610,1651 and 310 thousand hectares at SWZ, CPZ and SMZ which was subsequently increased up to 849,1805 and 410 thousand hectares until 2017, in respective zones. Similarly, the corresponding yield of the rice has also increased in Punjab over the years. In 2017, rice productivity of 4239,4474 and $3824 \mathrm{kgha}^{-1}$ had been increased by $16.8,19.2$ and $17.3 \%$ from 3526,3616 and $3161 \mathrm{kgha}^{-1}(2000)$, respectively in southwestern, central plain and sub-mountainous zones (Table 3 ).

\section{Water footprint assessment}

The edapho-climatic-management factors and inherent geno-morphological characters of the selected cultivar influenced the WFP of the cultivation process. Minimum $\mathrm{WF}_{\text {green }}$ of rice production was 328 litre $\mathrm{kg}^{-1}$ (during 2000) in south western zone 552 litre $\mathrm{kg}^{-1}$ (during 2002) under central plain, and 894 litre $\mathrm{kg}^{-1}$ (during 2012) under sub-mountainous regions (Table 3 ) due to low rainfall of $162.6 \mathrm{~mm}$ (in SWZ) $500 \mathrm{~mm}$ (in SMZ) and $355.4 \mathrm{~mm}$ (in CPZ), respectively. On the other hand, heavy rainfall $558.4 \mathrm{~mm}$ (at SWZ during 2016), $1133.4 \mathrm{~mm}$ (at SMZ during 2008) and $1192 \mathrm{~mm}$ (at CPZ during 2011) correspondingly responded to maximum $\mathrm{WF}_{\text {green }}$ of 2670,1998 and 2214 litre $\mathrm{kg}^{-1}$ rice. An increase in the $\mathrm{WF}_{\text {blue }}$ reveals the high irrigation water input applied for crop production. Mekonnen and Hoekstra (2010) also reported that the most significant $\mathrm{WF}_{\text {blue }}$ among the cereals is for rice and wheat crops, and both of these together accounts for $45 \%$ of the blue water footprint globally.

The total water footprint $\left(\mathrm{WF}_{\text {total }}\right)$ is the summation of the water consumed as evaporation and transpiration from precipitation $\left(\mathrm{WF}_{\text {green }}\right)$ and through irrigation $\left(\mathrm{WF}_{\text {blue }}\right)$ over the entire crop growth season at a given location. Thus, it largely depends upon the climatic and water management factors. Our results described that in the study period, $\mathrm{WF}_{\text {total }}$ was 2095-3003, 2069-3002 and 2650-3578 litre $\mathrm{kg}^{-1}$ rice in south western, central plain and submountainous regions. The average WFP in the respective regions was 2482, 2490 and 2976 litre $\mathrm{kg}^{-1}$. Distribution of $\mathrm{WF}_{\text {total }}$ between the $\mathrm{WF}_{\text {green }}$ and $\mathrm{WF}_{\text {blue }}$ was 22.8 and $77.2 \%$ in south-western zone, 32.7 and $67.3 \%$ in central plains, and 38.8 and $61.2 \%$ in sub-mountainous zones. These results revealed the values of $\mathrm{WF}_{\text {total }}$, and the $\mathrm{WF}_{\text {green }}$ of rice increased from south-western zone towards the central and submountainous regions of the state, whereas, the $\mathrm{WF}_{\text {blue }}$ followed the opposite fashion (Table3). For whole Punjab state, the minimum and maximum $\mathrm{WF}_{\text {green }}$ was 646 (2012) and 1149 litre $\mathrm{kg}^{-1}$ (during 2001), $\mathrm{WF}_{\text {blue }}$ was in the range of 150 (during 2017) and 2254 litre $\mathrm{kg}^{-1}$ of rice (during 2002). Hence, the highest $\mathrm{WF}_{\text {total }}$ of rice production 3010 and 3181 litre $\mathrm{kg}^{-1}$ rice during 2000 and 2001, which considerably reduced up to 2300 litre $\mathrm{kg}^{-1}$ rice during the year 2017. Share of $\mathrm{WF}_{\text {green }}$ and $\mathrm{WF}_{\text {blue }}$ in the $\mathrm{WF}_{\text {total }}$ was 32 and $68 \%$, respectively (Fig. 3 ). 


\section{CONCLUSION}

The WFP of a product is the sum of the WF of various activities involved in the entire production process. The $\mathrm{WF}_{\text {green }}$ is particularly relevant for agricultural produce as a higher $\mathrm{WF}_{\text {green }}$ means effective use of rainwater for meeting the ETneed of crops and thereby reducing the amount of irrigation water required for its cultivation $\left(\mathrm{WF}_{\text {blue }}\right)$. Thus, the $\mathrm{WF}_{\text {blue }}$ is highly dependent on the amount and temporal distribution of rainfall during the crop season as more the $\mathrm{P}_{\text {eff }}$, lesser the irrigation requirement. The $\mathrm{WF}_{\text {green }}$ during the study period improved with synchronization of date of transplanting of rice with the onset of monsoon through the implementation of Act of 2009, and it varied from328 (SWZ) to 1503 liter $\mathrm{kg}^{-1}$ (SMZ) while, $\mathrm{WF}_{\text {blue, }}$, varied from 1429 (CPZ) to 1954 liter $\mathrm{kg}^{-1}$ (SMZ).During the study period, irrigated transplanted rice on an average consumed about 2650 liters of water per kilogram of production $\left(\mathrm{WF}_{\text {total }}\right)$, and out of this, about 1804 liters of water (68\%) was applied as irrigation. The change in crop calendar by legally prohibiting the early transplanting of rice up to mid-June, coupled with theimprovement in rice productivity, has primarily contributed to the reduction in the consumptive water footprint of rice production in the state.

\section{REFERENCES}

Allen, R.G., Pereira, L.S., Raes, D. and Smith, M. (1998). Crop evapotranspiration: Guidelines for computing crop water requirements, FAO Irrigation and Drainage Paper 56, FAO, Rome, Italy.

Bosire, C.K., Lannerstad, M., Leeuw, J.D., Krol, M.S., Ogutu, J.O., Ochungo, P.A. and Hoekstra, A.Y. (2017). Urban consumption of meat and milk and its green and blue water footprints Patterns in the 1980s and 2000s for Nairobi, Kenya. Sci. Total Environ. 579, 786-796.

Brar, S.K., Mahal, S.S., Brar,A.S., Vashist, K.K., Sharma, N. and Buttar, G.S. (2012). Transplanting time and seedling age affect water productivity, paddy yield, and quality in north-west India. Agric. Water Manage., 115:217-222.

Brar, A.S., Buttar, G.S., Jhanji, D., Neerja, N., Vashist, K.K., Mahal, S.S., Deol, J.S. and Singh, G. (2015). Water productivity, energy, and economic analysis of transplanting methods with different irrigation regimes in basmati rice (Oryza sativa L.) in North-Western India. Agric. Water Manage., 158:189-195.
Civit, B., Piastrellini, R., Curadelli, S. andArena,A.P.(2018). The water consumed in the production of grapes for vinification (Vitisvinifera). Mapping the blue and green water footprint. Ecol. Indic., 85, 236-243.

CGWB, Center Groundwater Board (2018). Groundwater yearbook, 2013-14. Ministry of Water Resource, Government of India, New Delhi.

Dastane, N.G. (1978). Effective rainfall in irrigated agriculture. Land and Water Development Division, Italy, Rome.

Hoekstra, A.Y.(2009). Human appropriation of natural capital: A comparison of ecological footprint and water footprint analysis. Ecol. Econ., 68:1963 -74.

Hoekstra, A.Y., Chapagain, A.K., Aldaya, M.M. andMekonnen, M.M.(2011). The Water Footprint Assessment Manual: Setting the Global Standard (Earthscan, London).

Kaur, J., Gill, K.K., Kaur, S. andAggarwal, R. (2017). Estimation of crop coefficient for rice and wheat crops at Ludhiana. J. Agrometeorol., 19(2):170-171.

Mekonnen, M.M. and Hoekstra, A.Y. (2010). Aglobal and highresolution assessment of the green, blue, and grey water footprint of wheat. Hydrol. Earth Syst Sci., 14(7): 12591276.

Mekonnen, M.M. and Hoekstra, A.Y. (2011). The green, blue and grey water footprint of crops and derived crop products.Hydrol. Earth Syst. Sci., 15: 1577-1600,

Prihar, S.S., Khepar, S.D., Singh, R., Grewal, S.S. and Sondhi, S.K.(1993). Water Resources of Punjab-Acritical concern for the future of its agriculture, Punjab Agricultural University, Research Bulletin, p 60.

Sharma, B.R.,Ambili, G.K. and Sidhu, B.S. (2010). The Punjab Preservation of Subsoil Water Act: a regulatory mechanism for saving groundwater. In: Rao, M.S.,Khobragade, S., Kumar, B., Singh, R.D. (Eds.). Proceedings of the Workshop on Water Availability and Management in Punjab (WAMIP-2010), Chandigarh, India, 13-15 December 2010. Roorkee, India: National Institute of Hydrology. pp.405-414.

Zhuo, L., Mekonnen, M.M. and Hoekstra A.Y. (2016). The effect of inter-annual variability of consumption, production, trade, and climate on crop-related green and blue water footprints and inter-regional virtual water trade: Astudy for China (1978-2008). Water Res. 